\title{
Peripheral ulcerative keratitis: A review of aetiology and management
}

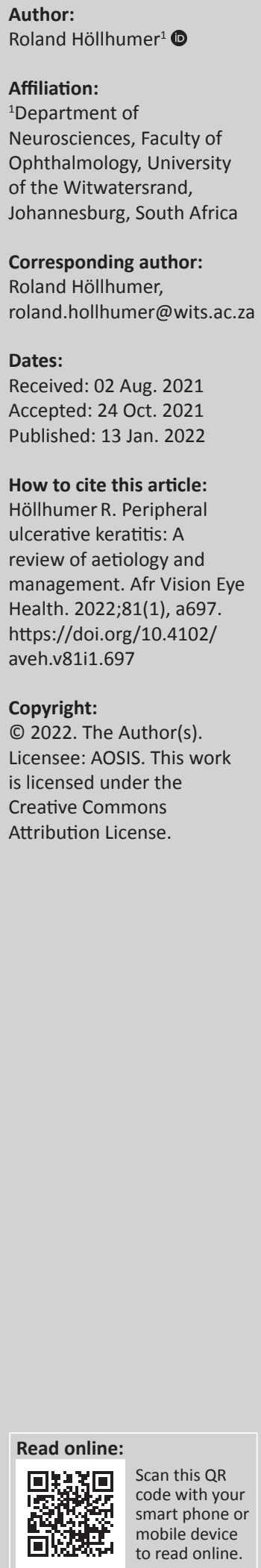

Background: Peripheral ulcerative keratitis (PUK) is a severe inflammatory disease of the peripheral cornea that can be caused by local factors or systemic inflammatory disease.

Aim: The purpose of this review is to give an overview of the pathophysiology, aetiology, clinical features, diagnosis, and management of PUK.

Method: A PubMed search was conducted using the keywords, 'peripheral ulcerative keratitis' and 'Mooren's ulcer'.

Results: The peripheral cornea has unique characteristics the predispose to the development of PUK. These include fine capillary arcades that allow for deposition of immune complexes and subsequent activation of an inflammatory cascade with corneal melt. Several conditions have been implicated in the aetiology of PUK. The most commonly cited causes are rheumatoid arthritis (RA), granulomatosis with polyangiitis (GPA) and various dermatoses. In patients with RA, PUK usually presents in established disease, whereas in GPA, PUK may be the presenting feature in up to $60 \%$ of cases. In RA it heralds the onset of a systemic vasculitis with significant associated morbidity and mortality. The management of PUK follows an individualised stepwise approach. All patients require supportive measures to encourage healing and halt the process of keratolysis. Systemic autoimmune conditions need a systemic corticosteroid as a fast-acting agent to halt the inflammatory process while cytotoxic therapy maintains long term disease control. Failure to achieve disease control with CTT, necessitates the use of a biologic agent.

Conclusion: Peripheral ulcerative keratitis is a severe inflammatory disease of the peripheral cornea that needs a thorough diagnostic workup and stepwise management approach.

Keywords: peripheral ulcerative keratitis; immunosuppression; cytotoxic therapy; biologic therapy; rheumatoid arthritis; granulomatosis with polyangiitis.

\section{Introduction}

Peripheral ulcerative keratitis (PUK) is a rare inflammatory disease of the peripheral cornea with an incidence of $0.2-3.0$ per million population per year. ${ }^{1}$ It is characterised by a juxtalimbal crescent shaped epithelial defect, stromal thinning and inflammatory stromal infiltrate. ${ }^{1}$ Peripheral ulcerative keratitis develops in the peripheral cornea because of its unique anatomical and physiological characteristics. ${ }^{1}$ It is associated with many local and systemic conditions that are broadly classified into infective and non-infective. ${ }^{1}$

Peripheral ulcerative keratitis is an important condition as the presence of comorbid systemic disease is associated with significant morbidity and increased mortality. ${ }^{2}$ It may be the first presentation of systemic disease, and early diagnosis and management has the potential to not only preserve vision but also reduce mortality. ${ }^{2}$ The purpose of this review was to provide an overview of the pathophysiology, aetiology, clinical features, diagnosis and management of PUK. A PubMed search was conducted using the keywords, 'peripheral ulcerative keratitis' and 'Mooren's ulcer'.

\section{Pathophysiology}

The peripheral cornea has several unique characteristics that make the individual vulnerable to the development of inflammatory disease. ${ }^{3}$ Capillary arcades from the anterior ciliary arteries extend $0.5 \mathrm{~mm}$ into clear cornea, and the collagen fibres are tightly packed in the corneal periphery. ${ }^{3,4}$ These characteristics allow for the deposition of high-molecular-weight molecules, such as immune complexes, immunoglobulin $\mathrm{M}(\operatorname{IgM})$ and the first component of the complement cascade, $\mathrm{C} 1 .^{3}$ Lymphatics in the subconjunctiva extend into the peripheral cornea, creating access to the afferent limb of the immune system, whilst the adjacent conjunctiva is thought to act as a reservoir for inflammatory cells and cytokines in the efferent limb of the immune response. ${ }^{3,4,5}$ 
The exact mechanism of PUK is not fully understood. The basic tenets of the process are the deposition of circulating immune complexes in the limbal vascular arcades. ${ }^{3}$ This causes an activation of the classical complement pathway and resultant vasculitis. ${ }^{3}$ The subsequent chemotaxis of inflammatory cells into the peripheral cornea results in the release of proinflammatory cytokines and matrix metalloproteinases (MMP), ${ }^{4}$ MMP-2 and 9 hydrolyse type 4 collagen, altogether leading to epithelial breakdown and stromal melt., 3,6,7 This occurs in a crescentic fashion and is the hallmark of PUK. ${ }^{1}$

\section{Aetiology}

The causes of PUK are extensive (Figure 1) and can be divided into systemic and local causes. Non-infectious causes account for half the cases, with rheumatoid arthritis (RA) cited as the most common associated systemic disease in approximately $34 \%$ of the cases. ${ }^{1,8}$ Other important associations include granulomatosis with polyangiitis (GPA), inflammatory bowel disease (IBD), human immunodeficiency virus (HIV), hepatitis $\mathrm{C}$ and dermatological conditions. The most common local ocular conditions are bacterial and viral keratitis that involve the peripheral cornea. ${ }^{1}$

\section{Rheumatoid arthritis}

Rheumatoid arthritis is an autoimmune disease that is characterised by chronic inflammation of the joints, resulting in damage to the underlying cartilage and bone. ${ }^{9}$ In developed countries, the prevalence rate of RA is $0.5 \%-1 \%$ of adults compared with a higher prevalence of $0.13 \%-2.5 \%$ in developing countries. ${ }^{9,10}$ Women are affected three times more than men, with a peak incidence over the age of 65 years. ${ }^{9,11,12}$ Associated risks have not been fully elucidated; however, genetic factors are thought to account for $50.0 \%$ of the risk, and smoking doubles the risk of developing RA. ${ }^{9}$

The diagnosis of RA is based on the American College of Rheumatology (ACR)/European Alliance of Associations for Rheumatology (EULAR) criteria of $2010 . .^{13}$ This criteria take into account synovitis, serology for antibodies, acute phase reactants and the duration of symptoms. ${ }^{13}$ Synovitis is diagnosed clinically by the presence of tender and swollen large or small joints. ${ }^{13}$ Serology can be performed for diagnostic antibodies in RA, which can precede the clinical onset of disease by several years. ${ }^{13}$ These include rheumatoid factor (RF) and anti-citrullinated protein antibodies (ACPA). ${ }^{9,13}$ Rheumatoid factor are the classic anti-bodies where IgM and immunoglobulin A (IgA) rheumatoid factors are directed against the $F_{C}$ fragment of immunoglobulin $G(\operatorname{IgG}) .{ }^{9}$ Anticitrullinated protein antibodies are more specific and sensitive for the diagnosis of RA and are associated with a more severe course of disease and poorer outcomes. ${ }^{9}$ These have been found to be positive in $50 \%-80 \%$ of patients with RA. ${ }^{9}$

The management of RA revolves around two pillars, symptom management and disease modification. ${ }^{9}$ Analgesia and nonsteroidal anti-inflammatory drugs help to reduce the symptoms of pain and stiffness; however, these have no effect on disease progression. ${ }^{9}$ Disease-modifying anti-rheumatic drugs (DMARDS) are a group of agents that are used to

\begin{tabular}{|c|c|}
\hline Systemic & Local \\
\hline Bacterial & Bacterial \\
\hline \multicolumn{2}{|l|}{ Mycobacterium tuberculosis $48,61,63$} \\
\hline Syphilis ${ }^{41,64}$ & Viral \\
\hline Cat scratch disease ${ }^{65}$ & Herpes simplex ${ }^{63,66,67,68}$ \\
\hline Lyme disease $^{69}$ & Herpes zoster 63,70 \\
\hline \multicolumn{2}{|l|}{ Gonococcal keratoconjunctivitis ${ }^{71,72,73}$} \\
\hline & Fungal \\
\hline \multicolumn{2}{|l|}{ Viral } \\
\hline HIV $^{35,37,38,39,40,41,42}$ & Parasitic \\
\hline Hepatitis $C^{44,45,46,47,48,49}$ & Acanthamoeba keratitis $s^{63,74}$ \\
\hline \multicolumn{2}{|l|}{ Hepatitis B $75,76,77$} \\
\hline Autoimmune causes & Autoimmune causes \\
\hline $\begin{array}{l}\text { Rheumatoid } \\
\text { arthritis } 11,12,15,16,17,18,19,33,40,48,53,63,66,78,79,80,81,82\end{array}$ & Mooren's ulcer \\
\hline \multicolumn{2}{|l|}{ Granulomatosis with polyangiitis ${ }^{26,27,28,62,63,83,84}$} \\
\hline Polyarteritis nodosa ${ }^{85}$ & Trauma \\
\hline Relapsing polychondritis ${ }^{76}$ & Chemical injury ${ }^{86}$ \\
\hline Systemic lupus erythematosis ${ }^{88,89}$ & Beatle shell ${ }^{87}$ \\
\hline \multicolumn{2}{|l|}{ Spondyloarthopathy ${ }^{88}$} \\
\hline Microscopic polyangiitis ${ }^{88,90,91}$ & Surgery \\
\hline Eosinophilic granulomatosis with polyangiitis ${ }^{93}$ & Cataract surgery ${ }^{17,92}$ \\
\hline Psoriatic arthritis ${ }^{88}$ & Pterygium surgery ${ }^{94}$ \\
\hline Inflammatory bowel disease ${ }^{30,31,32,33,88}$ & Trabeculectomy ${ }^{18}$ \\
\hline Behcet's disease ${ }^{88,96,97}$ & LASIK $^{95}$ \\
\hline Temporal arteritis ${ }^{75}$ & Collagen cross linking ${ }^{98}$ \\
\hline Juvenile idiopathic arthritis ${ }^{99}$ & Cycloablation $^{19}$ \\
\hline \multicolumn{2}{|l|}{ Ocular cicatricial pemphigoid ${ }^{100}$} \\
\hline & Other \\
\hline Dermatological & Traditional eye medication $^{101}$ \\
\hline Psoriasis $^{103}$ & Ocular surface squamous neoplasia ${ }^{102}$ \\
\hline \multicolumn{2}{|l|}{ Hidradenitis supurativa ${ }^{104}$} \\
\hline \multicolumn{2}{|l|}{ Pyoderma gangrenosum ${ }^{51,52,53,54}$} \\
\hline \multicolumn{2}{|l|}{ Erythema elevatum diutinum $56,57,58,59$} \\
\hline \multicolumn{2}{|l|}{ Sweet syndrome ${ }^{53,60,61,62}$} \\
\hline \multicolumn{2}{|l|}{ Pityriasis rubra pilaris ${ }^{105}$} \\
\hline \multicolumn{2}{|l|}{ Cancer } \\
\hline \multicolumn{2}{|l|}{ Chronic myeloid leukaemia $^{52}$} \\
\hline \multicolumn{2}{|l|}{ Acute lymphocytic leukaemia ${ }^{106,107}$} \\
\hline \multicolumn{2}{|l|}{ Multiple myeloma $^{108}$} \\
\hline \multicolumn{2}{|l|}{\begin{tabular}{|l|} 
Other \\
\end{tabular}} \\
\hline \multicolumn{2}{|l|}{ Chronic granulomatous disease ${ }^{109}$} \\
\hline \multicolumn{2}{|l|}{ Sarcoidosis ${ }^{110}$} \\
\hline \multicolumn{2}{|l|}{ Mixed cryoglobulinaemia ${ }^{44,45,46,76,77}$} \\
\hline \multicolumn{2}{|l|}{ Membranous glomerulonephropathy ${ }^{95}$} \\
\hline \multicolumn{2}{|l|}{ Autoimmune hepatitis $^{111}$} \\
\hline \multicolumn{2}{|l|}{ Gout $^{112}$} \\
\hline \multicolumn{2}{|l|}{ Paraquat poisoning ${ }^{113}$} \\
\hline Haemolytic uraemic syndrome ${ }^{114}$ & \\
\hline
\end{tabular}

HIV, human immunodeficiency virus.

FIGURE 1: Causes of peripheral ulcerative keratitis.

halt the progression of disease, thereby reducing morbidity and mortality. ${ }^{9}$ The most commonly used agent in RA is methotrexate followed by more expensive biological agents. ${ }^{9}$

Rheumatoid arthritis is the most common systemic association with PUK, present in up to $75 \%$ of patients with a known systemic cause. ${ }^{14}$ The prevalence of PUK in RA is approximately $1.4 \%$, with a mean age of presentation of 65-73 years and a female preponderance. ${ }^{11,12,15}$ Peripheral ulcerative keratitis most commonly presents in patients 
with long-standing quiescent RA, rendering the ACR/ EULAR criteria less relevant in this situation. ${ }^{12}$ Although the mean duration of RA before the onset of PUK is 12-19 years, ${ }^{2,11,12,15}$ it may rarely be the presenting feature. ${ }^{16,17}$ Serology for RA antibodies in PUK has a higher positivity rate than non-PUK patients at $100 \%$ and $88 \%$ for $\mathrm{RF}$ and ACPA, respectively. ${ }^{12,13,15}$ Peripheral ulcerative keratitis may be bilateral in up to $52 \%$ of patients, and scleritis has been found to be present in 38\% - 100\%. ${ }^{2,15}$ Patients with RA have an increased risk of developing PUK after surgery, even if their systemic disease has been controlled for years. ${ }^{18,19}$ It is therefore important to have stringent followup in the initial post-operative period. Corneal perforation is a severe complication of PUK and has been reported in $15 \%-73 \%$ of patients with RA. . $^{11,12,14}$

The pathogenesis of PUK in patients with RA has not been fully described. The hypothesis is that immune complexes from the circulating antibodies deposit in the vascular arcades of the peripheral cornea and elicit an inflammatory cascade that leads to peripheral corneal melt and PUK. ${ }^{20}$ Peripheral ulcerative keratitis in RA is therefore thought to herald the onset of a systemic vasculitis which is associated with a significant 5 -year mortality. ${ }^{2}$ One study showed the development of systemic vasculitis in $22 \%$ of patients within two months of the onset of PUK and a $50 \%$ associated mortality. ${ }^{12}$ Malik et al. ${ }^{11}$ described a series of patients with RA and keratolysis. PUK was diagnosed in $55 \%$ of patients in this series, with a 5-year mortality rate of $24 \% .{ }^{11}$ With the increased utilisation of DMARDS and biologics, there has been a decrease in the prevalence of PUK and an increased life expectancy in patients with RA. ${ }^{2}$ Foster et al. ${ }^{2}$ compared patients with RA and PUK and/or scleritis and their outcomes with and without the use of cytotoxic therapy. Patients receiving CTT had a mortality rate of $6 \%$, whereas the patients who did not receive CTT had a mortality rate of $53 \% .^{2}$

Similarly, the incidence of perforation has been reduced in recent years with the increased use of modern therapy. A perforation rate of up to $73 \%$ in the past has been reduced to only $13 \%$ in more recent case series. ${ }^{11,15}$ Two case series reported in the same hospital over two successive time periods echoed these results. The perforation rate was 65\% between 1987 and 2002, which had reduced to $14 \%$ for the subsequent period from 2002 to $2012 .{ }^{11,14}$ This was largely attributed to the increased use of immunosuppressive therapy.

\section{Granulomatosis with polyangiitis}

Granulomatosis with polyangiitis is a multi-system autoimmune condition characterised by a small vessel vasculitis that classically affects the upper respiratory tract, lower respiratory tract and kidneys. ${ }^{21}$ In patients where kidney involvement is spared, the diseased to considered to be in a 'limited' form. ${ }^{22}$ The incidence ranges from 5 to 10 cases per million annually, with the peak age of onset between 65 years and 70 years. ${ }^{21}$ There is no gender predilection; however, the prevalence rate is higher amongst Caucasians. ${ }^{21,23}$

The onset of GPA is thought to be triggered by environmental or infectious factors in patients with an underlying genetic predisposition. ${ }^{21}$ The most common of these is a Staphylococcus Aureus colonisation of the nasal passages. ${ }^{21}$ This results in the activation of the complement system and production of pro-inflammatory cytokines that lead to the activation of neutrophils and anti-neutrophil associated antibodies (ANCAs). ${ }^{24}$ This creates a cycle of inflammation that leads to vasculitis and target organ damage. ${ }^{24}$

Granulomatosis with polyangiitis does not have defined diagnostic criteria. The diagnosis of this condition is based on a combination of clinical, serological and histological findings. ${ }^{21}$ The most common clinical findings include an upper and lower respiratory tract inflammation and features of a glomerulonephritis. ${ }^{21}$ Serology for ANCA is positive in $88 \%$ of GPA patients, but is not essential to make the diagnosis. ${ }^{21}$ In patients with 'limited' disease, the sensitivity of this test decreases to $50 \% .{ }^{24}$ Histology shows evidence of granulomatous inflammation and necrotising vasculitis in the target organ. ${ }^{21}$

The standard treatment for severe GPA is a combination of systemic corticosteroids (CS) and cyclophosphamide (CyP) for the induction of remission (3-6 months). Maintenance therapy consists of methotrexate or leflunomide.22 The CS/CyP combination achieves partial remission in $91 \%$ and complete remission in $75 \%$ of patients. ${ }^{23}$ In patients only receiving $\mathrm{CS}$, the condition is uniformly fatal..$^{23}$ The current challenge in the management of GPA is the reduction in the rate of recurrence. The CS/CyP combination still has a recurrence rate of $50 \% .^{23}$ This has led to the use of rituximab, which has been shown to be non-inferior to CS/CyP combination for induction therapy but superior for managing disease relapse and the prevention of major relapses..$^{24,25}$

Ocular involvement in GPA occurs in 50\% - 60\% of patients, with ocular features being the initial presentation of GPA in $8 \%-60 \%$ of patients. ${ }^{22,23,26}$ The most common ocular manifestations include scleritis, uveitis, PUK and orbital inflammation. ${ }^{22}$ Peripheral ulcerative keratitis is predominantly unilateral, with concomitant scleritis present in $80 \%$ of patients. ${ }^{26}$ Anti-neutrophil associated antibodies is positive in the majority of patients with PUK; however, GPA cannot be excluded if negative. ${ }^{26}$ The combination therapy of CS and CyP is effective for disease control in the majority of cases, ${ }^{26}$ however, in resistant cases, rituximab infusions have been successful. . $^{27,27,28}$

\section{Inflammatory bowel disease}

Inflammatory bowel diseases are a group of autoimmune conditions of the bowel, which include Chron's disease (CD) and ulcerative colitis (UC). ${ }^{29}$ The global prevalence is estimated at 147 cases/million with ocular involvement in $0.3 \%-13 \%$ of patients. ${ }^{29}$ The diagnosis is made on clinical 
presentation and confirmed with biopsies of the involved gastrointestinal tract. ${ }^{30}$ Ocular involvement includes mainly episcleritis and uveitis, with PUK as a rare association. . $^{29,30,31,32,33}$

Peripheral ulcerative keratitis in IBD can be the presenting feature of IBD or presents after previously diagnosed disease. $29,30,31,32,33$ It affects men and women equally, favouring a younger onset from 33 years to 55 years. ${ }^{29,30,31,32,33}$ This cohort of patients have a more severe form of PUK, with most needing escalation of immunosuppressive therapy to biological agents in order to achieve disease control. . $29,30,31,32,33^{2}$

\section{Human immunodeficiency virus}

The HIV, first described in the 1980s, has led to a worldwide pandemic with its epicentre in Sub-Saharan Africa. ${ }^{34} \mathrm{New}$ infections continue to occur at a rate of 1.2 million cases a year. ${ }^{34}$ Human immunodeficiency virus primarily affects the cluster of differentiation 4 (CD4) T-lymphocyte population, with its depletion directly correlated with an acquired immune deficiency. ${ }^{34}$ Once the CD4 count falls under $200 / \mu L$, it is classified as an acquired immunodeficiency syndrome (AIDS). ${ }^{34}$ This immune deficiency predisposes individuals to a range of opportunistic infections and cancers. ${ }^{34}$

The spread of disease occurs primarily through sexual transmission. ${ }^{34}$ Diagnosis is made on serology, with the stage of disease determined by the CD4 cell count or presence of an acquired immunodeficiency syndrome (AIDS)-defining condition. ${ }^{34}$ Highly active antiretroviral therapy is the preferred treatment regimen consisting of a combination of three agents that suppress viral replication. ${ }^{34}$ This allows for recovery of the immune system and has reduced morbidity and mortality rates by $80 \%{ }^{34}$ The effectiveness of Highly active antiretroviral therapy (HAART) is monitored by the reduction in serum viral load. ${ }^{34}$

The pathophysiology of PUK in HIV is two pronged. Firstly, the chronic HIV infection causes high levels of circulating immune complexes. ${ }^{35}$ As described earlier, these can precipitate in the peripheral cornea and initiate an inflammatory cascade with resultant keratolysis. Secondly, HIV predisposes to other infective conditions, which in themselves may be associated with PUK. ${ }^{36}$

HIV has been described as a cause of PUK in several case reports. $35,37,38,39,40,41,42$ This association has been made in newly diagnosed patients with no co-morbid conditions or in the presence of conditions associated with PUK..$^{38,39,42}$ These associated conditions were mostly infective in nature and included tuberculosis, herpes zoster ophthalmicus, RA, and syphilis. ${ }^{35,37,40,41}$

All the patients who had HIV as an isolated risk for PUK required only local therapy and initiation of HAART in order to achieve disease control, suggesting that HIV alone is not an aggressive factor for the development of PUK..$^{38,39,42}$

\section{Hepatitis C}

Hepatitis $\mathrm{C}$ virus (HCV) is a systemic infection with a global seroprevalence rate of $3 \%{ }^{43}$ Transmission occurs through blood contact with an infected individual. ${ }^{43}$ In the past, this occurred mainly from blood transfusions, but this method of transmission has almost completely been abolished with improved screening at blood banks. ${ }^{43}$ The leading cause of $\mathrm{HCV}$ transmission currently is through the use of shared needles by intravenous drug users. ${ }^{43}$

Hepatitis C virus infection is mostly asymptomatic and resolves spontaneously within 18 months in $15 \%-25 \%$ of individuals. ${ }^{43}$ In patients with chronic $\mathrm{HCV}$ infection, the sequelae are variable, including chronic hepatitis with liver cirrhosis and failure, hepatocellular carcinoma, mixed cryoglobulinaemia (MC) and extra-hepatic manifestations. ${ }^{43}$ Mixed cryoglobulinaemia is a condition characterised by cold-insoluble immune complexes that deposit in small and medium blood vessels causing a vasculitis. ${ }^{43}$ More than $90 \%$ of patients with MC have HCV infection. ${ }^{43}$ In the case reports reviewed, half of the patients with PUK and HCV infection had associated MC. ${ }^{44,45,46}$ Elevated RF levels and reduced levels are $\mathrm{C} 3$ and $\mathrm{C} 4$ may be present in patients with $\mathrm{MC} .{ }^{43} \mathrm{~A}$ rare extrahepatic manifestation of both HCV infection and MC is the development of PUK. ${ }^{43}$

Peripheral ulcerative keratitis develops in chronic HCV infection, with associated necrotising scleritis being a common clinical finding. ${ }^{44,45,46,47,48,49}$ The management of choice for $\mathrm{HCV}$ infection is interferon-alpha and ribavirin. ${ }^{43}$ The patients who were refractory to this have responded well to a combination of interferon-alpha, ribavirin and rituximab. ${ }^{43}$

\section{Dermatosis}

Pyoderma gangrenosum is a neutrophilic dermatosis that is characterised by non-infective necrotic ulceration of the skin. ${ }^{50,51}$ It is a rare condition with an annual incidence of 3-10 per million. ${ }^{50}$ It is associated with a unilateral PUK that responds well to systemic CS and immunosuppression agents. . $^{50,51,52,53,54}$

Erythema elevatum diutinum (EED) is a rare chronic dermatosis that is characterised by brown to purple plaques of the extensor surfaces of the skin..$^{55}$ Diagnosis is confirmed on skin biopsy. ${ }^{55}$ Although EED occurs mainly in the age group 50-70 years, PUK associated with EED has been described in patients from 22 years to 81 years without a gender predisposition. $55,56,57,58,59$ All patients respond to dapsone therapy. ${ }^{55,56,57,58,59}$

Sweet syndrome is a neutrophilic dermatosis that is characterised by fever and sudden onset of painful erythematous nodules on the face, neck and extremities. ${ }^{60}$ It has several ocular manifestations of the anterior segment, including conjunctivitis, episcleritis, scleritis, anterior uveitis and glaucoma. ${ }^{60}$ Rarely, it may be associated with PUK. 53,60,61,62 Peripheral ulcerative keratitis, in this setting, is usually unilateral, may be associated with scleritis and disease control can be achieved with CS and/ or immunosuppression agents. ${ }^{53,60,61,62}$ 


\section{Clinical features}

The symptoms associated with PUK depend on the severity at presentation and the presence of associated scleritis. Most patients will present with pain, epiphora, conjunctival injection and reduced visual acuity. ${ }^{12}$ On further questioning and examination, features of associated diseases may be present. In conditions such as RA, the diagnosis will often already be made, and features of RA will be present. ${ }^{14}$ In other associated conditions, such as GPA, the PUK may be the presenting feature of the underlying disease. ${ }^{26}$

On clinical examination, visual acuity is reduced, conjunctiva is injected, and a crescentic epithelial defect with stromal infiltrate and thinning is present. ${ }^{63}$ The thinning and ulceration spread circumferentially before there is central spread (Figure 2). ${ }^{63}$ Associated features that may be present depend on the associated conditions and severity, which include scleritis, perforation, secondary infection, uveitis, hypopyon and raised intra-ocular pressures. $38,61,63$

\section{Diagnosis and workup}

The differential diagnosis for PUK is large, and a detailed history, systemic and ocular examination is needed to guide the workup for associated conditions. As some patients may present with more than one comorbidity is essential to do a workup in all patients even if a known comorbidity is present.

Basic blood investigations that should be conducted include full blood count with platelets and differential count; urea, creatinine and electrolytes; erythrocyte sedimentation rate; C-reactive protein and urinanalysis. ${ }^{1}$ More specific blood and radiological investigations are detailed in Figure 3. Some conditions may benefit from a biopsy to aid in the confirmation of a diagnosis (Table 1). All patients should have corneal scrapes performed to exclude an underlying infection. ${ }^{1}$

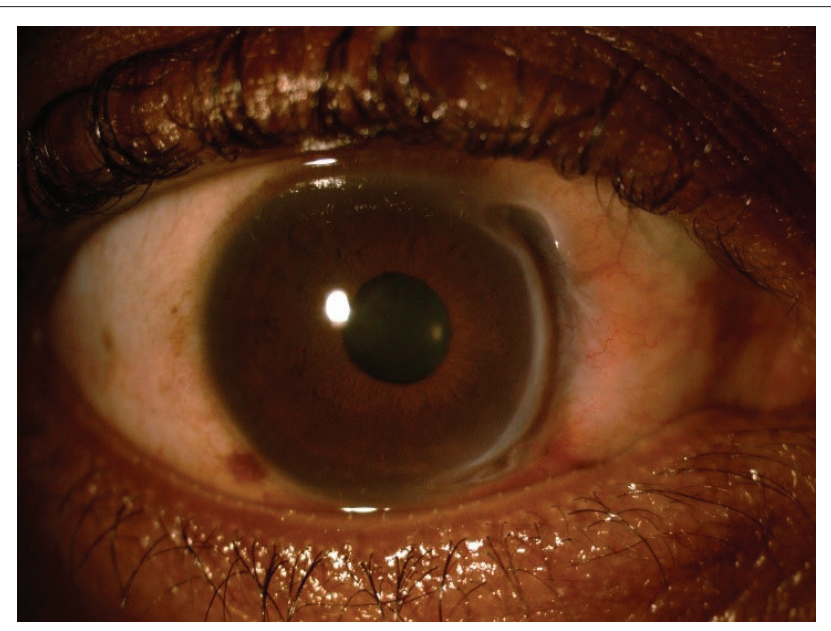

Source: Photo taken by Dr C Anderson

FIGURE 2: Anterior segment photograph of a right eye with peripheral ulcerative keratitis.

\section{Management}

The management of PUK is largely determined by the underlying cause. Infective causes need topical and/or systemic therapy, whilst other causes require individualised management approaches. The majority of PUK is associated

\begin{tabular}{|l|l|}
\hline Investigation & Reason \\
\hline HIV serology & HIV infection \\
\hline RPR and TPHA & Syphilis \\
\hline Hepatitis B and C & Hepatitis and cryoglobulinaemia \\
\hline Rheumatoid factor & Rheumatoid arthritis \\
\hline Anti-citrulinated antibodies & Rheumatoid arthritis \\
\hline $\begin{array}{l}\text { Anti-neutrophil cytoplasmic } \\
\text { antibodies }\end{array}$ & $\begin{array}{l}\text { Granulomatosis with polyangiitis, } \\
\text { microscopic polyangiitis, and } \\
\text { eosinophilic granulomatosis with } \\
\text { polyangiitis }\end{array}$ \\
\hline Antinuclear antibodies & Systemic lupus erythematosus \\
\hline Angiotensin-converting enzyme & Sarcoidosis \\
\hline Uric acid & Gout \\
\hline Chest X-ray & $\begin{array}{l}\text { Tuberculosis, sarcoidosis and } \\
\text { granulomatosis with polyangitis }\end{array}$ \\
\hline Mantoux test & Tuberculosis \\
\hline
\end{tabular}

Source: Adapted from Gupta et al. Peripheral ulcerative keratitis. Surv Ophthalmol. 2021;66(6):977-998. https://doi.org/10.1016/j.survophthal.2021.02.013

HIV, human immunodeficiency virus; RPR, rapid plasma regain; TPHA, Treponema pallidum hemagglutination.

FIGURE 3: Investigations for the workup of peripheral ulcerative keratitis.

TABLE 1: Conditions where a biopsy is useful to confirm the diagnosis.

\begin{tabular}{ll}
\hline Disease & Findings on histology \\
$\begin{array}{l}\text { Granulomatosis } \\
\text { with polyangiitis } \\
\text { Temporal arteritis }\end{array}$ & $\begin{array}{l}\text { Granulomatous inflammation and necrotising vasculitis in } \\
\text { the conjunctiva, and necrotising glomerulonephritis. }{ }^{21}\end{array}$ \\
$\begin{array}{l}\text { Granulomatous inflammation of the internal elastic layer of the } \\
\text { temporal artery. }{ }^{115}\end{array}$ \\
$\begin{array}{l}\text { Inflammatory } \\
\text { bowel disease }\end{array}$ & $\begin{array}{l}\text { Inflammation of the mucosa and superficial submucosa in } \\
\text { ulcerative colitis and transmural inflammation and } \\
\text { epithelioid granulomas in Chron's disease. }{ }^{115}\end{array}$ \\
Sarcoidosis & $\begin{array}{l}\text { Granulomas with epithelial histocytes and non-caseating } \\
\text { necrosis. }{ }^{115}\end{array}$ \\
$\begin{array}{l}\text { Ocular cicatricial } \\
\text { pemphigoid }\end{array}$ & $\begin{array}{l}\text { Linear deposits of immunoglobulins and complement on the } \\
\text { conjunctival basement membrane and positive direct } \\
\text { immunofluorescence. }\end{array}$ \\
$\begin{array}{l}\text { Psoriasis } \\
\text { Pyoderma }\end{array}$ & $\begin{array}{l}\text { Regular epidermal hyperplasia. }{ }^{115} \\
\text { vessel necrosis. }{ }^{117}\end{array}$ \\
$\begin{array}{l}\text { gangrenosum } \\
\text { Erythema elevatum the dermis and hypodermis with small } \\
\text { diutinum }\end{array}$ & $\begin{array}{l}\text { Vascular infiltrate of upper-to-mid dermis, storiform sclerosis } \\
\text { and plasma cells. }{ }^{118}\end{array}$ \\
$\begin{array}{l}\text { Sweet syndrome } \\
\text { Nityriasis rubra } \\
\text { pilaris }\end{array}$ & $\begin{array}{l}\text { Foutrophil infiltrate of the dermis with the absence of vasculitis. }{ }^{60} \\
\text { infiltrate of the dermis. }{ }^{105}\end{array}$ \\
$\begin{array}{l}\text { Ocular surface } \\
\text { squamous neoplasia }\end{array}$ & $\begin{array}{l}\text { Thickened disorganised conjunctival epithelium with mitotic } \\
\text { figures superficial to the basal epithelium. }{ }^{119}\end{array}$ \\
\hline
\end{tabular}

with underlying autoimmune disease, and thus, the focus of this review is to provide an overview of the management options for this group of patients. ${ }^{12,15}$ The main goals of therapy in these patients were to control the systemic and local inflammatory process, halt keratolysis, prevent infection and promote healing (Figure 4).

\section{Medical Topical}

In autoimmune disease, topical therapy has a supportive role and cannot be used as monotherapy. Topical anti-inflammatory 
agents, such as CS, cyclosporin and tacrolimus, have been successfully used as an adjunct., ${ }^{2,120}$ Topical steroids should be used with caution as they inhibit collagen synthesis and may increase the risk of perforation. ${ }^{21}$ Topical collagenase inhibitors canbeused tohaltkeratolysisand include $1 \%$ medroxyprogesterone and 20\% N-acetylcysteine. ${ }^{21}$ Lubricants and serum derivatives can be used to promote healing of the ocular surface. ${ }^{2}$

\section{Systemic}

Wound healing may cause a local deficiency of vitamin C, and therefore, oral vitamin C (500 mg BD [twice a day]) has been shown to have a positive effect on wound healing, whilst oral doxycycline (100 mg BD) helps to inhibit collagenolysis by inhibiting MMP. ${ }^{2}$

Systemic corticosteroids (oral or intravenous [IV]) have a rapid onset of action and are the initial treatment of choice for patients with an underlying autoimmune disease. . $^{31,88,121,122}$ Intravenous methyl prednisolone is usually given at $1 \mathrm{~g}$ for 3 days and oral prednisone at $1 \mathrm{mg} / \mathrm{kg}$ per day to a maximum of $60 \mathrm{mg} /$ day. ${ }^{1}$ They do have significant side effects and do not show a disease-modifying effect, and therefore, need to be combined with additional therapies. ${ }^{1,20}$

Cytotoxic therapies are steroid sparing agents that have become the mainstay of therapy for PUK associated with autoimmune disease. These agents include CyP, methotrexate, azathioprine, mycophenolate mofetil and cyclosporine A (Table 2). Cytotoxic therapy takes 4-6 weeks to reach efficacy, and therefore, a cross taper with CS is

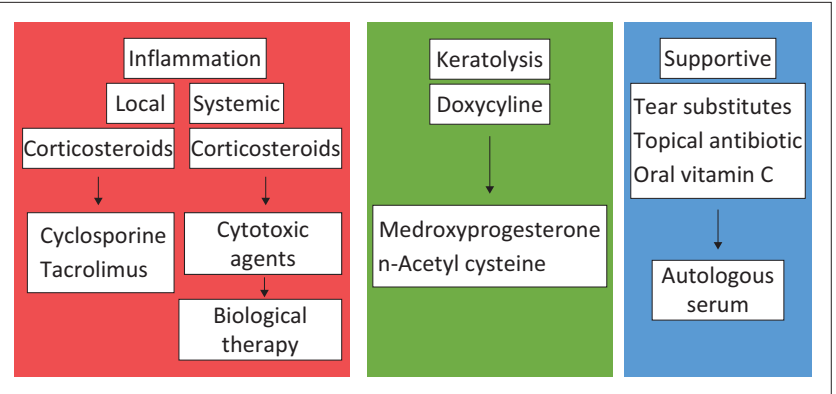

FIGURE 4: Stepladder approach to the medical management of autoimmune associated peripheral ulcerative keratitis. important to maintain a constant anti-inflammatory effect. ${ }^{1}$ Foster et al. ${ }^{2}$ was the first to highlight the benefit of CTT in patients with RA and PUK. He highlighted that PUK is an early indicator of the progression of RA from articular disease to systemic vasculitis with significant associated mortality. ${ }^{2}$ They reported a mortality rate of $53 \%$ in patients not using CTT compared with $6 \%$ in those who did over a 10-year follow-up. ${ }^{2}$ The patients who received CTT had no adverse events that required hospitalisation. ${ }^{2}$ Ogra et al. ${ }^{123}$ reviewed mortality rates in patients with PUK and necrotising scleritis, and found that CTT increased time to death from 11 years to 25 years. Similar findings were found in subsequent case series, which has led to the universal adoption of CTT in PUK associated with autoimmune disease..$^{8,122,124,125}$ The use of CTT has also increased the effectiveness of other treatment modalities, such as keratoplasty. ${ }^{122}$

Biological therapy forms the next step in the immunosuppression ladder for PUK. The biologics can roughly be divided into anti-tumour necrosis factor alpha (TNF $\alpha$ ) (adalimum$\mathrm{ab}$, infliximab, and etanercept) and non-TNF $\alpha$ (rituximab, tocilizumab, belimumab, and abatacept) groups (Table 3). Patients who fail combination corticosteroid and cytotoxic therapy can be started on one of the biologics. ${ }^{16,31,33,88,121,125,126,127}$ Geetha et al. ${ }^{128}$ compared rituximab with oral CyP in ANCAassociated vasculitis, and found that it was non-inferior to $\mathrm{CyP}$ and possibly better at preventing relapsing disease. ${ }^{128} \mathrm{~A}$ recent study showed greater efficacy of the non-TNF $\alpha$ agents in the management of PUK. ${ }^{88}$ Forty-eight percent of patients in the anti-TNF $\alpha$ group needed to change to another biological agent, whereas none of the patients in the non-TNF $\alpha$ group needed to change therapy. ${ }^{88}$ This study also found that $18 \%$ of patients using biologics developed severe adverse events that required either a change in therapy or a change to another agent. ${ }^{88}$ One of the most commonly used biologics is rituximab. There are two main treatment doses for rituximab, $500 \mathrm{mg}$ or $1000 \mathrm{mg}$. Both are given two weeks apart at the initiation of treatment, which can be repeated at six months. Several studies compared the efficacy of these two regimens and found that clinical response was not statistically different between the two, but that the higher dose was more effective at halting joint damage in patients with RA. ${ }^{129,130,131,132}$ When

TABLE 2: Cytotoxic agents for the management of autoimmune peripheral ulcerative keratitis.

\begin{tabular}{|c|c|c|c|c|c|}
\hline Agent & Mechanism of action & Route & Dosage & Side effects & Cost \\
\hline Cyclophosphamide & Alkylating agent & IV & $1 \mathrm{~g}$ monthly & Leukopenia, GIT upset, haemorrhagic cystitis. & R254.00/month \\
\hline Methotrexate & Anti-metabolite & $\mathrm{PO}$ & $7.5 \mathrm{mg}-25 \mathrm{mg}$ weekly & $\begin{array}{l}\text { Hepatotoxicity, renal toxicity, leukopenia, } \\
\text { stomatitis, nausea, fatigue. }\end{array}$ & R32.00-R100.00/month \\
\hline Azathioprine & Purine synthesis inhibitor & PO & $1.0 \mathrm{mg} / \mathrm{kg}-2.5 \mathrm{mg} / \mathrm{kg}$ per day & $\begin{array}{l}\text { Neoplasia, GIT upset, hypersensitivity reactions, } \\
\text { hepatotoxicity, renal toxicity. }\end{array}$ & R365.00-R851.00/month $\dagger$ \\
\hline $\begin{array}{l}\text { Mycophenolate } \\
\text { mofetil }\end{array}$ & $\begin{array}{l}\text { Inosine-5'-monophosphate } \\
\text { dehydrogenase inhibitor }\end{array}$ & PO & $1.0 \mathrm{~g}-1.5 \mathrm{~g}$ daily & $\begin{array}{l}\text { Malaise, fatigue, GIT upset, leukopenia, liver } \\
\text { dysfunction. }\end{array}$ & R1539.00-R2308.00/month \\
\hline Cyclosporine A & Calcineurin inhibitor & PO & $\begin{array}{l}1.25 \mathrm{mg} / \mathrm{kg} \mathrm{BD} \\
\text { Increase after } 8 \text { weeks by } \\
0.5 \mathrm{mg} \text { to } \max 4 \mathrm{mg} / \mathrm{kg} \text { per } \\
\text { day according to response }\end{array}$ & $\begin{array}{l}\text { Leukopenia, nephrotoxicity, hyperkalaemia, } \\
\text { hypomagnesaemia, gum hyperplasia, pancreatitis, } \\
\text { anaphylaxis, tremor, infections, hypertension, } \\
\text { dizziness, nausea, hirsutism. }\end{array}$ & R4700.00† \\
\hline
\end{tabular}

Source: Adapted from Gupta Y, et al. Peripheral ulcerative keratitis. Surv Ophthalmol. 2021;66(6):977-998. https://doi.org/10.1016/j.survophthal.2021.02.013

Note: Cost of medication derived from www.medicineprices.org.za.

IV, intravenous; PO, per os; GIT, gastrointestinal tract; $\mathrm{BD}$, twice a day.

$\uparrow$, Dose calculated for a $70-\mathrm{kg}$ patient; $\$$, dose calculated at $1.25 \mathrm{mg} / \mathrm{kg}$ BD for a $70-\mathrm{kg}$ patient. 
TABLE 3: Biological agents for the management of autoimmune peripheral ulcerative keratitis.

\begin{tabular}{|c|c|c|c|c|c|}
\hline Agent & Mechanism of action & Route & Dosage & Side effects & Cost \\
\hline \multicolumn{6}{|l|}{ Anti-TNF $\alpha$} \\
\hline Adalimumab & $\begin{array}{l}\text { Anti-TNF } \alpha \\
\text { monoclonal antibody }\end{array}$ & SC & $40 \mathrm{mg}$ every second week & Malignancies, infection and anaphylaxis & R7292.00/month \\
\hline Infliximab & $\begin{array}{l}\text { Anti-TNF } \alpha \\
\text { monoclonal antibody }\end{array}$ & IV & $\begin{array}{l}3 \mathrm{mg} / \mathrm{kg}-5 \mathrm{mg} / \mathrm{kg} \text { per dose given at } \\
0,2,6 \text { weeks and then every } 8 \text { weeks. }\end{array}$ & $\begin{array}{l}\text { Reactivation of pulmonary tuberculosis, infection } \\
\text { risk, lupus-like reaction and demyelinating disease. }\end{array}$ & $\begin{array}{l}\text { R8074.00-R12 } 111.00 \text { per } \\
\text { infusion }{ }^{\dagger}\end{array}$ \\
\hline Etanercept & $\begin{array}{l}\text { Anti-TNF } \alpha \\
\text { monoclonal antibody }\end{array}$ & SC & $25 \mathrm{mg}$ twice a week or $50 \mathrm{mg}$ weekly & Serious infections and reactivation of infections & R18684.00/month \\
\hline \multicolumn{6}{|l|}{ non-TNF $\alpha$} \\
\hline Rituximab & $\begin{array}{l}\text { Anti-CD20 } \\
\text { monoclonal antibody }\end{array}$ & IV & $\begin{array}{l}\text { Two infusions of } 1000 \mathrm{mg}, 2 \text { weeks } \\
\text { apart. Can be repeated after } 6 \text { months. }\end{array}$ & $\begin{array}{l}\text { Infusion-related reactions, cardiac toxicity and } \\
\text { infection reactivations }\end{array}$ & R77 448.00 per infusion cycle \\
\hline Tocilizumab & $\begin{array}{l}\text { Anti-IL6 monoclonal } \\
\text { antibody }\end{array}$ & SC or IV & $\begin{array}{l}162 \mathrm{mg} \mathrm{SC} \text { weekly or } 4 \mathrm{mg} / \mathrm{kg} \mathrm{IV} \\
\text { monthly }\end{array}$ & $\begin{array}{l}\text { Serious infections, reactivation of infections, and } \\
\text { infusion reactions }\end{array}$ & $\begin{array}{l}\text { R9111.00/month or } \\
\text { R4783.00/month } \dagger\end{array}$ \\
\hline Abatacept & $\begin{array}{l}\text { CD80/86 receptor } \\
\text { inhibitor }\end{array}$ & SC or IV & $\begin{array}{l}500 \mathrm{mg}-1000 \mathrm{mg} \mathrm{IV} \text { at } 0,2,4 \text {, and then } \\
4 \text { weekly or } 125 \mathrm{mg} \text { SC weekly }\end{array}$ & $\begin{array}{l}\text { Serious infections, reactivation of infections and } \\
\text { infusion reactions }\end{array}$ & $\begin{array}{l}\text { R5240.00 - R10 } 480.00 / \\
\text { infusion or R8509.00/month }\end{array}$ \\
\hline
\end{tabular}

Source: Adapted from Gupta et al. Peripheral ulcerative keratitis. Surv Ophthalmol. 2021;66(6):977-998. https://doi.org/10.1016/j.survophthal.2021.02.013

Note: Cost of medication derived from www.medicineprices.org.za.

IV, intravenous; SC, subcutaneous; TNFa, tumour necrosis factor alpha; CD20, cluster of differentiation.

$\dagger$, Infusion calculated for a $70-\mathrm{kg}$ patient.

assessing the response to therapy, it has been shown that patients with a high lymphocyte and plasmablast count do not perform well on rituximab therapy, and that the 6-month dose is not uniformly required. ${ }^{16}$ This should be kept in mind when choosing a biological agent.

\section{Surgical}

\section{Disease control}

The basic pathogenesis of autoimmune PUK is the deposition of immune complexes in the limbal vascular arcades with activation of the complement system and associated immune response. It has been shown that the conjunctiva adjacent to the area of PUK has collagenase activity, whereas distant conjunctival sites do not. ${ }^{5}$ This led to the idea that removing the conjunctiva adjacent to the ulcer would reduce the source of inflammatory enzymes and reduce the corneal melting process. . $, 8,133,134$ Conjunctival resection was favoured as a treatment modality from the 1970 s to 1990 s..$^{5,8,133,134}$ It was mostly found to be useful in patients without an associated conjunctival vasculitis. ${ }^{8,135}$ The use has subsequently been less reported, most likely because of the increased utilisation and effectiveness of systemic therapies, such as CS, cytotoxic and biological agents.

\section{Tectonic}

Corneal perforation is a severe complication of PUK, which can be managed by several ways, including corneal glue, multi-layer amniotic membrane or a corneal patch graft (full thickness or lamellar). ${ }^{11,125,126}$ Corneal glue is a simple office procedure to seal a small corneal perforation..$^{20}$ This is often a temporising procedure before definitive surgery; however, this occasionally may allow for healing without further surgery. Before the regular use of CTT and biological agents, the need for corneal patch grafts was as high as $56 \%-75 \%$ with loss of the globe occurring in $10 \%-21 \%$ of patients. ${ }^{11,12,122,135}$ Fortunately, with the increased use of biological agents, the need for patch grafts has reduced to $12 \%-14 \%$ with good tissue survival and improved visual outcomes. ${ }^{15,126}$ Patients with GPA seem to have a more severe course of disease, with $50 \%-60 \%$ of patients requiring patch grafts to maintain globe integrity despite the use of CTT and biologics. ${ }^{26,125}$ Various techniques have been described to assist the surgeon in fashioning these crescentic grafts. ${ }^{136,137,138,139}$

\section{Discussion}

Peripheral ulcerative keratitis is a severe inflammatory condition of the peripheral cornea that can be caused by local factors or systemic inflammatory disease. The peripheral cornea has unique characteristics that make the individual liable to the development of PUK. These include fine capillary arcades that allow for deposition of immune complexes and subsequent activation of an inflammatory cascade with corneal melt.

Several conditions have been implicated in the aetiology of PUK. The most commonly reported systemic causes include RA, GPA and dermatoses. In patients with RA, the PUK usually presents in established disease, whereas in GPA it may be the presenting feature in up to $60 \%$ of cases. ${ }^{26}$ In RA, it heralds the onset of a systemic vasculitis with significantly associated morbidity and mortality. Because of the large number of associated conditions and the possibility of multiple associated conditions in one patient, it is important to conduct a full workup in all patients who present with PUK.

The management of PUK follows an individualised stepwise approach. All patients require supportive measures to encourage healing and halt the process of keratolysis (Figure 3). Systemic autoimmune conditions require systemic corticosteroids as a fast-acting agent to halt the inflammatory process. As there are many associated side effects with steroid therapy and they do not alter the course of disease for conditions such as RA, they should be combined with additional therapy. Cytotoxic therapy are the initial choice as disease modifying agents. The time to efficacy for CTT ranges from 4 to 6 weeks, and therefore, they should be commenced at the same time as the steroids with a cross taper in the dosing of both agents. Failure to achieve disease control with CTT necessitates the use of a biological agent. In order to ensure safe use of CTT and 
biological agents, these should be prescribed in conjunction with a rheumatologist.

As PUK is a challenging condition, a thorough workup for an underlying cause and managing the patient with a multidisciplinary team can improve ocular outcomes and reduce mortality rates.

\section{Acknowledgements}

The author would like to thank the staff at the Wits Health Sciences Library for their support in the development of this report. Dr C. Anderson provided the anterior segment photos, as shown in Figure 2.

\section{Competing interests}

The author declares that he has no financial or personal relationship that may have inappropriately influenced him in writing this article.

\section{Authors' contributions}

The author declares that he is the sole author of this research article.

\section{Ethical considerations}

This article followed all ethical standards standards for research without direct contact with human or animal subjects.

\section{Funding information}

The author received no financial support for the research authorship and/or publication of this article.

\section{Data availability}

Data sharing is not applicable to this article, as no new data were created or analysed in this study.

\section{Disclaimer}

The views and opinions expressed in this article are those of the author and do not necessarily reflect the official policy or position of any affiliated agency of the author.

\section{References}

1. Gupta $Y$, Kishore A, Kumari P, et al. Peripheral ulcerative keratitis. Surv Ophthalmol 2021;66(6):977-998. https://doi.org/10.1016/j.survophthal.2021.02.013

2. Foster CS, Forstot SL, Wilson LA. Mortality rate in rheumatoid arthritis patients developing necrotizing scleritis or peripheral ulcerative keratitis: Effects of systemic immunosuppression. Ophthalmology. 1984;91(10):1253-1263. https://doi.org/10.1016/S0161-6420(84)34160-4

3. Dana MR, Qian Y, Hamrah P. Twenty-five-year panorama of corneal immunology Emerging concepts in the immunopathogenesis of microbial keratitis, peripheral ulcerative keratitis, and corneal transplant rejection. Cornea. 2000;19(5):625-643. https://doi.org/10.1097/00003226-200009000-00008

4. Gomes BF, Santhiago MR. Biology of peripheral ulcerative keratitis. Exp Eye Res. 2021;204:108458. https://doi.org/10.1016/j.exer.2021.108458

5. Eiferman RA, Carothers DJ, Yankeelov JA. Peripheral rheumatoid ulceration and evidence for conjunctival collagenase production. Am J Ophthalmol. 1979;87(5): 703-709. https://doi.org/10.1016/0002-9394(79)90308-8
6. Geerling G, Joussen AM, Daniels JT, et al. Matrix metalloproteinases in sterile corneal melts. Ann N Y Acad Sci. 1999:878(1):571-574. https://doi.org/10.1111/ j.1749-6632.1999.tb07730.x

7. Smith VA, Hoh HB, Easty DL. Role of ocular matrix metalloproteinases in peripheral ulcerative keratitis. Br J Ophthalmol. 1999;83(12):1376-1383. https:// doi.org/10.1136/bjo.83.12.1376

8. Tauber J, Sainz de la Maza M, Hoang-Xuan T, Foster CS. An analysis of therapeutic decision making regarding immunosuppressive chemotherapy for peripheral ulcerative keratitis. Cornea. 1990;9(1):66-73. https://doi.org/10.1097/00003226199001000-00013

9. Scott DL, Wolfe F, Huizinga TWJ. Rheumatoid arthritis. Lancet. 2010;376(9746): 1094-1108. https://doi.org/10.1016/S0140-6736(10)60826-4

10. Usenbo A, Kramer V, Young T, Musekiwa A. Prevalence of arthritis in Africa: A systematic review and meta-analysis. PLoS One. 2015;10(8):1-19. https://doi. org/10.1371/journal.pone.0133858

11. Malik R, Culinane AB, Tole DM, Cook SD. Rheumatoid keratolysis: A series of 40 eyes. Eur J Ophthalmol. 2006;16(6):791-797. https://doi.org/10.1177/ 112067210601600602

12. Squirrell DM, Winfield J, Amos RS. Peripheral ulcerative keratitis 'corneal melt' and rheumatoid arthritis: A case series. Rheumatology. 1999;38(12):1245-1248. https://doi.org/10.1093/rheumatology/38.12.1245

13. Aletaha D, Neogi, T, Silman AJ, et al. Rheumatoid arthritis classification criteria: An American College of Rheumatology/European League Against Rheumatism collaborative initiative. Arthritis Rheum. 2010;62(9):2569-2581. https://doi. org/10.1002/art.27584

14. Knox Cartwright NE, Tole DM, Georgoudis P, Cook SD. Peripheral ulcerative keratitis and corneal melt: A 10-year single center review with historical comparison. Cornea. 2014;33(1):27-31. https://doi.org/10.1097/ICO.00000000 00000008

15. Watanabe $\mathrm{R}$, Ishii $\mathrm{T}$, Yoshida $\mathrm{M}$, et al. Ulcerative keratitis in patients with rheumatoid arthritis in the modern biologic era: A series of eight cases and literature review. Int J Rheum Dis. 2017;20(2):225-230. https://doi.org/10.1111/ 1756-185X.12688

16. Hardy S, Hashemi K, Catanese $M$, et al. Necrotising scleritis and periphera ulcerative keratitis associated with rheumatoid arthritis treated with rituximab. Klin Monbl Augen-heilkd. 2017;234(4):567-570. https://doi.org/10.1055/s-0042 121315

17. Akpek EK, Demetriades AM, Gottsch JD. Peripheral ulcerative keratitis after clea corneal cataract extraction. J Cataract Refract Surg. 2000;26(9):1424-1427. https://doi.org/10.1016/S0886-3350(00)00359-X

18. Papaconstantinou D, Georgopoulos G, Kalantzis G, Krassas A, Georgalas I. Peripheral ulcerative keratitis after trabeculectomy in a patient with rheumatoid arthritis. Cornea. 2009;28(1):111-113. https://doi.org/10.1097/ICO.0b013e31 $8182 \mathrm{fc01}$

19. Pérez Silguero D, Pérez Silguero MÁ, Pérez-Silguero Jiménez S, Encinas Pisa $P$. Peripheral ulcerative keratitis after ultrasound-mediated cycloablation in patients with rheumatoid arthritis. A possible causal relationship. Arch Soc Esp Oftalmol. 2020;95(4):196-200. https://doi.org/10.1016/j.oftal.2020.01.010

20. Cao Y, Zhang $\mathrm{W}, \mathrm{Wu} \mathrm{J}$, Zhang $\mathrm{H}$, Zhou H. Peripheral ulcerative keratitis associated with autoimmune disease: Pathogenesis and treatment. J Ophthalmol. 2017; 2017:7298026. https://doi.org/10.1155/2017/7298026

21. Lutalo PMK, D'Cruz DP. Diagnosis and classification of granulomatosis with polyangiitis (aka Wegener's granulomatosis). J Autoimmun. 2014;48-49:94-98. https://doi.org/10.1016/j.jaut.2014.01.028

22. Watkins AS, Kempen JH, Choi D, et al. Ocular disease in patients with ANCA positive vasculitis. J Ocul Biol Dis Inform. 2009;3:12-19. https://doi.org/10.1007/ s12177-009-9044-4

23. Hoffman GS, Kerr GS, Leavitt RY, et al. Wegener granulomatosis: An analysis of 158 patients. Ann Intern Med. 1992;116(6):488-498. https://doi.org/10.7326/ 0003-4819-116-6-488

24. Kronbichler A, Lee $\mathrm{KH}$, Denicolo $\mathrm{S}$, et al. Immunopathogenesis of ANCAassociated vasculitis. Int J Mol Sci. 2020;21(10):7319. https://doi.org/10.3390/ ijms21197319

25. David J, Trujillo P, Carlos J, Turizo M. Use of rituximab for granulomatosis with polyangiitis-associated peripheral ulcerative keratitis. Rev Colomb Reumatol. 2017;24(1):44-47. https://doi.org/10.1016/j.rcreue.2017.03.001

26. Gu J, Zhou S, Ding $R$, et al. Necrotizing scleritis and peripheral ulcerative keratitis associated with Wegener's granulomatosis. Ophthalmol Ther. 2013;2:99-111. https://doi.org/10.1007/s40123-013-0016-1

27. Huerva V, Sanchez MC, Traveset A, Jurjo C, Ruiz A. Rituximab for peripheral ulcerative keratitis with wegener granulomatosis. Cornea. 2010;29(6):708-710. https://doi.org/10.1097/ICO.0b013e3181c296ed

28. Fujita $Y$, Fukui S, Endo S, et al. Peripheral ulcerative keratitis associated with granulomatosis with polyangiitis emerging despite cyclophosphamide, successfully treated with rituximab. Intern Med. 2018;57(12):1783-1788. https://doi.org/10.2169/internalmedicine.0215-17

29. Troncoso LL, Biancardi AL, De Moraes HV, Zaltman C. Ophthalmic manifestations in patients with inflammatory bowel disease: A review. World J Gastroenterol. 2017;23(32):5836-5848. https://doi.org/10.3748/wjg.v23.i32.5836

30. Tan MH, Chen SDM, Rubinstein A, Bron AJ. Corneal perforation due to severe peripheral ulcerative keratitis in Crohn disease. Cornea. 2006;25(5):628-630. https://doi.org/10.1097/01.ico.0000214206.29823.2d

31. Pham $M$, Chow CC, Badawi D, Tu EY Use of infliximab in the treatment of peripheral ulcerative keratitis in Crohn disease. Am J Ophthalmol. 2011;152(2): 183-188. https://doi.org/10.1016/j.ajo.2011.01.059 
32. Angioi K, Kaminsky P, Peyrin-Biroulet L. Infliximab for severe peripheral ulcerative keratopathy revealing Crohn's disease. Inflamm Bowel Dis. 2011;17(3): 866-867. https://doi.org/10.1002/ibd.21358

33. Cordero-Coma M, Salazar Méndez R, Blanco ÁC, et al. Adalimumab for refractory peripheral ulcerative keratitis. J Ophthalmic Inflamm Infect. 2012;2:227-229. https://doi.org/10.1007/s12348-012-0080-z

34. Hirschel B. Infectious diseases - A clinical short course. New York: McGraw-Hill; 2007.

35. Pflugfelder SC, Saulson R, Ullman S. Peripheral corneal ulceration in a patient with AIDS-related complex. Am J Ophthalmol. 1987;104(5):542-543. https:// doi.org/10.1016/S0002-9394(14)74116-9

36. Dunn JP, Yamashita A, Kempen JH, Jabs DA. Retinal vascular occlusion in patients infected with human immunodeficiency virus. Retina. 2005;25(6):759-766. https://doi.org/10.1097/00006982-200509000-00012

37. Neves RA, Rodriguez A, Power W, et al. Herpes zoster peripheral ulcerative keratitis in patients with the acquired immunodeficiency syndrome. Cornea. 1996;15(5):446-450. https://doi.org/10.1097/00003226-199609000-00002

38. Gharai S, Venkatesh P, Tandon R, Garg S. Peripheral ulcerative keratitis and central retinal vein occlusion as the initial manifestation of HIV infection. 40701572404

39. Soni ND, Ingole AB, Murade SM. An unusual case of peripheral ulcerative keratitis as a presenting feature in an otherwise healthy patient with undiagnosed human immunodeficiency virus infection and low CD4 counts. Indian Ophthalmol. 2013;61(3):138-139. https://doi.org/10.4103/0301-4738.109391

40. Noche CD, Singwé-Ngandeu M, Bella AL. Rheumatoid polyarthritis suspected in an HIV patient with scleritis, peripheral ulcerative keratitis, and anterior uveitis. Int Med Case Rep J. 2016;9:19-24. https://doi.org/10.2147/IMCRJ.S94194

41. Ploysangam $P$, Mattern RM. Perforating peripheral ulcerative keratitis in syphilis. Case Rep Ophthalmol. 2019;10:267-273. https://doi.org/10.1159/000501996

42. Tavassoli S, Gunn D, Tole D, Darcy K. Peripheral ulcerative keratitis with corneal melt as the primary presentation in a case of human immunodeficiency virus.
BMJ Case Rep. 2019;12(2):10-13. https://doi.org/10.1136/bcr-2018-226936

43. Dammacco, F, editor. HCV infection and cryoglobulinemia. New York: Springer Science \& Business Media; 2012. https://doi.org/10.1007/978-88-470-1705-4

44. Johnson CC, Ohlstein DH. Peripheral ulcerative keratitis and necrotizing scleritis initiated by trauma in the setting of mixed cryoglobulinemia. Case Rep Ophthalmol. 2011;2:392-397. https://doi.org/10.1159/000334496

45. Kedhar SR, Belair M.-L, Jun AS, Sulkowski M, Thorne JE. Scleritis and peripheral ulcerative keratitis with hepatitis C virus-related cryoglobulinemia. Arch Ophthalmol. 2007;125(6):852-853. https://doi.org/10.1001/archopht.125.6.852

46. Coelho P, Menezes C, Gonçalves R, Rodrigues P, Seara E. Peripheral ulcerative keratitis associated with HCV-related cryoglobulinemia. Case Rep Ophthalmo Med. 2017;2017:9461937. https://doi.org/10.1155/2017/9461937

47. Pluznik D, Butrus SI. Hepatitis C-associated peripheral corneal ulceration: Rapid response to intravenous steroids. Cornea. 2001;20(8):888-889. https://doi. org/10.1097/00003226-200111000-00023

48. Morgan-Warren PJ, Dulku S, Ravindran J, Smith G. Peripheral ulcerative keratitis as the presenting feature of systemic rheumatoid vasculitis without joint involvement. Int Ophthalmol. 2014;34:933-935. https://doi.org/10.1007/s10792013-9879-3

49. El Bahloul M, Lambarki O, Bennis A, Chraïbi F, Abdellaoui M, Benatiya I. Severe chronic peripheral ulcerative keratitis: Approach to diagnosis and treatment. J Fr Ophtalmol. 2021;44(4):e231-e233. https://doi.org/10.1016/j.jfo.2020. 08.017

50. Hrin ML, Bashyam AM, Huang WW, Feldman SR. Mycophenolate mofetil as adjunctive therapy to corticosteroids for the treatment of pyoderm gangrenosum: A case series and literature review. Int J Dermatol. 2021;(12): e486-e492. https://doi.org/10.1111/ijd.15539

51. Imbernón-Moya A, Vargas-Laguna E, Aguilar A, et al. Peripheral ulcerative keratitis with pyoderma gangrenosum. Case Rep Dermatol Med. 2015;2015: 949840. https://doi.org/10.1155/2015/949840

52. Bouchard CS, Meyer MA, McDonnell JF. Bilateral peripheral ulcerative keratitis associated with pyoderma gangrenosum. Cornea. 1997;16(4):480-482. https:// doi.org/10.1097/00003226-199707000-00017

53. Wilson DM, John GR, Callen JP. Peripheral ulcerative keratitis - An extracutaneous neutrophilic disorder: Report of a patient with rheumatoid arthritis, pustular vasculitis, pyoderma gangrenosum, and Sweet's syndrome with an excellent vasculitis, pyoderma gangrenosum, and Sweet's syndrome with an excellent
response to cyclosporine therapy. J Am Acad Dermatol. 1999;40(2):331-334. https://doi.org/10.1016/S0190-9622(99)70479-2

54. Brown BA, Parker CT, Bower KS. Effective steroid-sparing treatment for peripheral ulcerative keratitis and pyoderma gangrenosum. Cornea. 2001;20(1):117-118. https://doi.org/10.1097/00003226-200101000-00023

55. Newburger J, Schmieder GJ. Erythema elevatum diutinum. Treasure Island: StatPearls; 2021

56. Takiwaki H, Kubo Y, Tsuda H, Arase S, Shiota H. Peripheral ulcerative keratitis associated with erythema elevatum diutinum and a positive rheumatoid factor: A report of three cases. Br J Dermatol. 1998;138(5):893-897. https://doi.org/ 10.1046/j.1365-2133.1998.02233.x

57. Aldave AJ, Shih JL, Jovkar S, McLeod SD. Peripheral keratitis associated with erythema elevatum diutinum. Am J Ophthalmol. 2003;135(3):389-390. https:// doi.org/10.1016/S0002-9394(02)02050-0

58. Vaiyavatjamai P, Wattanakrai P. Erythema elevatum diutinum associated with peripheral ulcerative keratitis. J Eur Acad Dermatol Venereol. 2011;25(6): 741-742. https://doi.org/10.1111/j.1468-3083.2010.03761.x
59. Jiao $\mathrm{T}$, Wang $\mathrm{M}$, Zhu X. A case of erythema elevatum diutinum associated with peripheral ulcerative keratitis. Australas J Dermatol. 2012:53(1):78-80. https:// doi.org/10.1111/j.1440-0960.2011.00816.x

60. Bilgin $A B$, Tavas $P$, Turkoglu EB, Ilhan HD, Toru S, Apaydin KC. An uncommon ocular manifestation of sweet syndrome: Peripheral ulcerative keratitis and nodular scleritis. Arq Bras Oftalmol. 2015;78(1):53-55. https://doi.org/10.5935/ 0004-2749.20150015

61. Gupta N, Chawla B, Venkatesh P, Tandon R. Necrotizing scleritis and peripheral ulcerative keratitis in a case of Sweet's syndrome found culture-positive for Mycobacterium tuberculosis. Ann Trop Med Parasitol. 2008;102(6):557-560. https://doi.org/10.1179/136485908X311812

62. Benzimra J, Low-Beer J, Twomey J. A case of peripheral ulcerative keratitis associated with neutrophilic dermatosis of the dorsal hand. Int Ophthalmol. 2011;31:149-151. https://doi.org/10.1007/s10792-011-9428-x

63. Sainz De La Maza M, Stephen Foster C, Jabbur NS, Baltatzis S. Ocula characteristics and disease associations in scleritis-associated peripheral keratopathy. Arch Ophthalmol. 2002;120(1):15-19. https://doi.org/10.1001/ archopht.120.1.15

64. Vignesh AP, Srinivasan R, Vijitha S. Ocular syphilis masquerading as bilateral peripheral ulcerative keratitis. Taiwan J Ophthalmol. 2016;6(4):204-205. https://doi.org/10.1016/j.tjo.2016.06.002

65. Prasher P, Di Pascuale M, Cavanagh HD. Bilateral chronic peripheral ulcerative keratitis secondary to cat-scratch disease. Eye Contact Lens. 2008;34(3):191-193. https://doi.org/10.1097//CL.0b013e31815788be

66. Zaher SS, Sandinha T, Roberts F, Ramaesh K. Herpes simplex keratitis misdiagnosed as rheumatoid arthritis-related peripheral ulcerative keratitis. misdiagnosed as roumea. 2005:24(8):1015-1017. https://doi.org/10.1097/01.ico.0000159758. 36230.c1

67. Chranioti A, Malamas A, Metallidis S, Mataftsi A, Chalvatzis N, Ziakas N. Bilateral herpes simplex virus-related peripheral ulcerative keratitis leading to corneal perforation in a patient with primary herpes simplex virus infection. J Ophthalmic Vis Res. 2019;14(1):93-96. https://doi.org/10.4103/jovr.jovr_3_17

68. Praidou A, Androudi S, Kanonidou E, et al. Bilateral herpes simplex keratitis presenting as peripheral ulcerative keratitis. Cornea. 2012;31(5):570-571. https://doi.org/10.1097/ICO.0b013e31822f3c18

69. DeLuise VP, O'Leary MJ. Peripheral ulcerative keratitis related to Lyme disease Am J Ophthalmol. 1991;111(2):244-245. https://doi.org/10.1016/S0002-9394(14) 72270-6

70. Mondino BJ, Brown SI, Mondzelewski JP. Peripheral corneal ulcers with herpes zoster ophthalmicus. Am J Ophthalmol. 1978;86(5):611-614. https://doi.org/ 10.1016/0002-9394(78)90176-9

71. Samira N, Bani AP, Susiyanti M. Rare case of bilateral perforated corneal ulcer due to gonococcal infection, managed with temporary periosteal graft. BM Case Rep. 2016;2016:1-4. https://doi.org/10.1136/bcr-2015-213547

72. Kawashima M, Kawakita T, Den S, Tomita M, Shimazaki J. Surgical management of corneal perforation secondary to gonococcal keratoconjunctivitis. Eye. of corneal perforation secondary to gonococcal keratoco

73. Kiritoshi S, Soma T. Corneal perforation secondary to gonococcal keratoconjunctivitis. CMAJ. 2020;192(44):E1361. https://doi.org/10.1503/cmaj. 200506

74. Moreira AT, Prajna NV. Acanthamoeba as a cause of peripheral ulcerative keratitis Cornea. 2003;22(6):576-577. https://doi.org/10.1097/00003226-20030800000018

75. Papathanassiou M, Elezoglou A, Nikita E, Theodossiadis PG, Vergados I. A rare case of peripheral ulceraitve keratitis in temporal arteritis. Eur J Ophthalmol. 2009;19(5):866-869. https://doi.org/10.1177/112067210901900529

76. Lai THT, Far N, Young AL, Jhanji V. Rapid corneal thinning and perforated ulcerative keratitis in a patient with relapsing polychondritis. Eye Vis. 2017;4:8-11. https://doi.org/10.1186/s40662-017-0073-y

77. Aiello F, Congliaro P, Malaspina C, Gallo Afflitto G, Nucci C. Peripheral ulcerative keratitis as the primary clinical manifestation of type 2 cryoglobulinemia. Can Ophthalmol. 2021;56(5):E148-E150. https://doi.org/10.1016/j.jcjo.2021.02.024

78. Atchia II, Kidd CE, Bell RWD. Rheumatoid arthritis-associated necrotizing scleritis and peripheral ulcerative keratitis treated successfully with infliximab. J Clin Rheumatol. 2006;12(6):291-293. https://doi.org/10.1097/01.rhu.0000249766. Rheumatol.
24780.95

79. Pokharel A, Subedi S, Bajracharya M. Peripheral ulcerative keratitis triggered by bacterial conjunctivitis. Nepal J Ophthalmol. 2010;2(1):71-73. https://doi.org/ 10.3126/nepjoph.v2i1.3709

80. Antao SF, Ayoub T, Tahir H, Parmar DN. Stabilization of bilateral progressive rheumatoid corneal melt with infliximab. Case Rep Ophthalmol Med. 2012;2012:173793. https://doi.org/10.1155/2012/173793

81. Lee WS, Choi YJ, Yoo WH, Yoo WH. Rapid progressive peripheral ulcerative keratitis associated with longstanding rheumatoid arthritis. J Rheumatol. 2016;43(10):1909-1910. https://doi.org/10.3899/jrheum.160262

82. Benchérifa S, Amine B, El Binoune I, Rostom S, Bahiri R. Two cases of perforated corneal ulcers complicating rheumatoid arthritis treated successfully by biological therapy. BMC Rheumatol. 2020;4:4-8. https://doi.org/10.1186/s41927-0190108-1

83. Wertheim MS, Ross AH, Tole DM. The use of Campath in severe peripheral ulcerative keratitis associated with Wegener's granulomatosis. Eye. 2006;20: 1453-1454. https://doi.org/10.1038/sj.eye.6702330

84. Liang J, Fan W, Yuan RD. Peripheral ulcerative keratitis and otitis media as initial symptoms of Wegener's granulomatosis: A case report. Int J Ophthalmol. 2019;12(5):873-876. https://doi.org/10.18240/ijo.2019.05.30 
85. Akova YA, Jabbur NS, Foster CS. Ocular presentation of polyarteritis nodosa: Clinical course and management with steroid and cytotoxic therapy. Ophthalmology. 1993;100(12):1775-1781. https://doi.org/10.1016/S0161 6420(93)31405-3

86. Iovieno A, Anand S, Dart JK. Late-onset peripheral ulcerative sclerokeratitis associated with alkali chemical burn. Am J Ophthalmol. 2014;158(6):1305-1309. e4. https://doi.org/10.1016/j.ajo.2014.08.038

87. Tiwari NN, Kodavoor S, Ramamurthy D, et al. Peripheral ulcerative keratitis: An extremely rare case presentation after Paederus (beetle) injury. Indian Ophthalmol. 2019;67(1):120-121. https://doi.org/10.4103/ijo.IJO 605 18

88. Dominguez-Casas LC, Sánchez-Bilbao L, Calvo-Río V, et al. Biologic therapy in severe and refractory peripheral ulcerative keratitis (PUK). Multicenter study of 34 patients. Semin Arthritis Rheum. 2020;50(4):608-615. https://doi.org/ 10.1016/j.semarthrit.2020.03.023

89. Heiligenhaus A, Dutt JE, Stephen Foster C. Histology and immunopathology of systemic lupus erythematosus affecting the conjunctiva. Eye. 1996;10:425-432. https://doi.org/10.1038/eye.1996.94

90. Mahendradas P, Galiyugavaradhan S, Shivanna Y, et al. Peripheral ulcerative keratitis in children owing to P-ANCA-associated vasculitis. Can J Ophthalmol. 2020;55(5):e175-e178. https://doi.org/10.1016/j.jcjo.2020.04.012

91. Keenan JD, Mandel MR, Margolis TP. Peripheral ulcerative keratitis associated with vasculitis manifesting asymmetrically as fuchs superficial marginal keratitis and terrien marginal degeneration. Cornea. 2011;30(7):825-827. https://doi. org/10.1097/ICO.0b013e3182000c94

92. Salamon SM, Mondino BJ, Zaidman GW. Peripheral corneal ulcers, conjunctival ulcers, and scleritis after cataract surgery. Am J Ophthalmol. 1982;93(3):334-337. https://doi.org/10.1016/0002-9394(82)90535-9

93. Bawazeer AM, Jackson WB. Marginal infiltrative ulcerative keratitis secondary to Churg-Strauss syndrome: A case report. Cornea. 2000;19(3):402-404. https:// doi.org/10.1097/00003226-200005000-00030

94. Gokhale NS. Peripheral ulcerative keratitis after pterygium surgery. Indian J Ophthalmol. 2003;51:105-106.

95. Burkholder BM, Kuo IC. Peripheral ulcerative keratitis following laser in situ keratomileusis. Case Rep Ophthalmol. 2016;7:9-15. https://doi.org/10.1159/ 000443324

96. Murphy C, Gregory ME, Ramaesh K. Peripheral ulcerative keratitis: An unusual primary ocular manifestation in Behçet's disease? Rheumatology. 2009;48(12):1490. https://doi.org/10.1093/rheumatology/kep232

97. Ji YS, Yoon KC. A rare case of peripheral ulcerative keratitis associated with Behçet's disease. Int Ophthalmol. 2014;34:979-981. https://doi.org/10.1007/ s10792-014-9910-3

98. Chanbour W, Mokdad I, Mouhajer A, Jarade E. Late-onset sterile periphera ulcerative keratitis post-corneal collagen crosslinking. Cornea. 2019;38:338-343. https://doi.org/10.1097/ICO.0000000000001842

99. Papathanassiou M, Zampeli E, Kaplanoglou T, Theodossiadis P. Periphera ulcerative keratitis in a patient with systemic-onset juvenile idiopathic arthritis. J Pediatr Ophthalmol Strabismus. 2010;47(6):1-3. https://doi.org/10.3928/ 01913913-20101018-05

100. Kiire CA, Srinivasan S, Inglis A. Peripheral ulcerative keratitis after cataract surgery in a patient with ocular cicatricial pemphigoid. Cornea. 2011;30(10): 1176-1178. https://doi.org/10.1097/ICO.0b013e3182141baa

101. Lewallen S, Courtright P. Peripheral corneal ulcers associated with use of African traditional eye medicines. Br J Ophthalmol. 1995;79(4):343-346. https://doi org/10.1136/bjo.79.4.343

102. Ganger A, Devi S, Gupta N, Vanathi M, Tandon R. Ocular surface squamous neoplasia masquerading as peripheral ulcerative keratitis. Trop Doct. 2017;47(3): 233-236. https://doi.org/10.1177/0049475516682133

103. Boss JM, Peachey RDG, Easty DL, Thomsitt J. Peripheral corneal melting syndrome in association with psoriasis: A report of two cases. Br Med J. 1981;282:609-610. https://doi.org/10.1136/bmj.282.6264.609-a

104. Mahmood MA, Pillai S, Limaye SR. Peripheral ulcerative keratitis associated with hideradenitis suppurativa. Cornea. 1991;10(1):75-78. https://doi.org/10.1097/ 00003226-199101000-00016

105. Paranjothy B, Shunmugam M, MacKenzie J, Azuara-Blanco A. Periphera ulcerative keratitis in pityriasis rubra pilaris. Eye. 2007;21:1001-1002. https:// doi.org/10.1038/sj.eye.6702797

106. Chawla B, Agarwal P, Tandon R, Titiyal JS. Peripheral ulcerative keratitis with bilateral optic nerve involvement as an initial presentation of acute lymphocytic leukemia in an adult. Int Ophthalmol. 2009;29:53-55. https://doi.org/10.1007/ s10792-007-9167-1

107. Morjaria R, Barge T, Mordant D, Elston J. Peripheral ulcerative keratitis as complication of acute myeloid leukaemia. BMJ Case Rep. 2014;2014:bcr2014 206399. https://doi.org/10.1136/bcr-2014-206399

108. Lim LT, Ramamurthi S, Collins CE, Mantry S. Peripheral ulcerative keratitis associated with multiple myeloma. Ann Acad Med Singapore. 2011;40: 550-551.

109. Leroux K, Mallon E, Ayliffe WH. Chronic granulomatous disease and periphera ulcerative keratitis: A rare case of recurrent external ocular disease. Bull Soc Belge Ophtalmol. 2004;(293):47-53.

110. Siracuse-Lee D, Saffra N. Peripheral ulcerative keratitis in sarcoidosis: A case report. Cornea. 2006;25(5):618-620. https://doi.org/10.1097/01.ico.0000183486. 93259.c9
111. Eshraghi H, Mahtabfar A, Dastjerdi MH. A case of peripheral ulcerative keratitis associated with autoimmune hepatitis. Case Rep Med. 2017:2017:3939413. https://doi.org/10.1155/2017/3939413

112. Yazdanyar A, Rizzuti AE, Mechel E, Denisova K, Lazzaro DR. Gout keratitis: A case of peripheral ulcerative keratitis secondary to gout with a review of the literature. Cornea. 2018;37(3):379-381. https://doi.org/10.1097/ICO.0000000000001415

113. Lo J, Poon LYC. Systemic paraquat intoxication presenting with peripheral ulcerative keratitis: A case report and literature review. Ocul Immunol Inflamm. 2020;28(6):871-875. https://doi.org/10.1080/09273948.2019.1640882

114. Mishra AV, Cadieux DC, Gjerde H, Lewis DR. Peripheral ulcerative keratitis secondary to atypical hemolytic uremic syndrome. Cornea. 2020;39(11): 1431-1432. https://doi.org/10.1097/ICO.0000000000002317

115. Reisner H. Pathology: A modern case study [hoempage on the Internet]. 2nd ed AccessMedicine. McGraw-Hill Medical. [cited 2021 May 31]. Available from: https://0-accessmedicine-mhmedical-com.innopac.wits.ac.za/book.aspx? bookid=2748

116. Wang K, Seitzman G, Gonzales JA. Ocular cicatricial pemphigoid. Curr Opin Ophthalmol. 2018;29(6):543-551. https://doi.org/10.1097/ICU.000000000 0000517

117. Scheinberg M, Machado LAM, Castro LG, Ferreira SB, Michalany N. Successful treatment of ulcerated pyoderma gangrenosum with baricitinib, a novel JAK inhibitor. J Transl Autoimmun. 2021;4:100099. https://doi.org/10.1016/j.jtauto. 2021.100099

118. Yaycıoğlu A, Vural S, Anadolu R. A rare presentation of erythema elevatum diutinum with annular lesions on the trunk. Dermatol Ther. 2021:34:7-9. https://doi.org/10.1111/dth.14566

119. Höllhumer R, Michelow P, Williams S. Diagnosis and staging of ocular surface squamous neoplasia. African Vis Eye Heal. 2020;79(1):1-8. https://doi.org/ 10.4102/aveh.v79i1.590

120. Miyazaki D, Tominaga T, Kakimaru-Hasegawa A, Nagata Y, Hasegawa J, Inoue $Y$. Therapeutic effects of tacrolimus ointment for refractory ocular surface inflammatory diseases. Ophthalmology. 2008;115(6):988-992. https://doi.org/ 10.1016/j.ophtha.2007.07.025

121. Thomas JW, Pflugfelder SC. Therapy of progressive rheumatoid arthritisassociated corneal ulceration with infliximab. Cornea. 2005;24(6):742-744. https://doi.org/10.1097/01.ico.0000154391.28254.1d

122. Messmer EM, Foster CS. Destructive corneal and scleral disease associated with rheumatoid arthritis. Med Surg Manag. Cornea. 1995;14(4):408-417. https:// doi.org/10.1097/00003226-199507000-00010

123. Ogra S, Sims JL, McGhee CNJ, Niederer RL. Ocular complications and mortality in peripheral ulcerative keratitis and necrotising scleritis: The role of systemic immunosuppression. Clin Exp Ophthalmol. 2020;48(4):434-441. https://do org/10.1111/ceo.13709

124. Jifi-Bahlool H, Saadeh C, O'Connor J. Peripheral ulcerative keratitis in the setting of rheumatoid arthritis: Treatment with immunosuppressive therapy. Semin Arthritis Rheum. 1995;25(1):67-73. https://doi.org/10.1016/S0049-0172(95)80019-0

125. Ebrahimiadib N, Modjtahedi BS, Roohipoor R, Anesi SD, Foster CS. Successful treatment strategies in granulomatosis with polyangiitis-associated peripheral ulcerative keratitis. Cornea. 2016;35(11):1459-1465. https://doi.org/10.1097/ c0.0000000000000919

126. Bonnet I, Rousseau A, Duraffour $P$, et al. Efficacy and safety of rituximab in peripheral ulcerative keratitis associated with rheumatoid arthritis. RMD Open. 2021;7(1):e001472. https://doi.org/10.1136/rmdopen-2020-001472

127. Albert M, Beltrán E. Short communication Rituximab in rheumatoid arthritisassociated peripheral ulcerative keratitis. Arch Soc Española Oftalmol. 2011:86(4): 118-120. https://doi.org/10.1016/j.oftal.2011.01.003

128. Geetha D, Specks U, Stone JH, et al. Rituximab versus cyclophosphamide for ANCA-associated vasculitis with renal involvement. J Am Soc Nephrol. 2015;26(4):976-985. https://doi.org/10.1681/ASN.2014010046

129. Emery P, Deodhar A, Rigby WF, et al. Efficacy and safety of different doses and retreatment of rituximab: A randomised, placebo-controlled trial in patients who are biological naive with active rheumatoid arthritis and an inadequate response to methotrexate (Study Evaluating Rituximab's Effi. Ann Rheum Dis. 2010;69(9):1629-1635. https://doi.org/10.1136/ard.2009.119933

130. Tak PP, Rigby WF, Rubbert-Roth A, et al. Inhibition of joint damage and improved clinical outcomes with rituximab plus methotrexate in early active rheumatoid arthritis: The IMAGE trial. Ann Rheum Dis. 2011;70(1):39-46. https://do org/10.1136/ard.2010. 137703

131. Rubbert-Roth A, Tak PP, Zerbini C, et al. Efficacy and safety of various repeat treatment dosing regimens of rituximab in patients with active rheumatoid arthritis: Results of a Phase III randomized study (MIRROR). Rheumatology. 2010;49(9):1683-1693. https://doi.org/10.1093/rheumatology/keq116

132. Chatzidionysiou K, Lie E, Nasonov E, et al. Effectiveness of two different doses of rituximab for the treatment of rheumatoid arthritis in an international cohort: Data from the CERERRA collaboration. Arthritis Res Ther. 2016;18:1-6. https:// doi.org/10.1186/s13075-016-1048-4

133. Wilson FM, Grayson M, Ellis FD. Treatment of peripheral corneal ulcers by limbal conjunctivectomy. Br J Ophthalmol. 1976;60(10):713-719. https://doi. org/10.1136/bjo.60.10.713

134. Feder RS, Krachmer $\mathrm{JH}$. Conjunctival resection for the treatment of the rheumatoid corneal ulceration. Ophthalmology. 1984;91(2):111-115. https:// doi.org/10.1016/S0161-6420(84)34319-6

135. Raizman MB, Sainz de la Maza M, Foster CS. Tectonic keratoplasty for periphera ulcerative keratitis. Cornea. 1991;10(4):312-316. https://doi.org/10.1097/ 00003226-199107000-00006 
136. Bafna RK, Kalra N, Asif MI, et al. Novel technique of tetra trephination for ellipticalshaped tectonic patch grafts in peripheral sterile keratolysis. Eur J Ophthal-mol. In press 2021;31(5):2769-2775. https://doi.org/10.1177/1120672121998955

137. Parmar GS, Ghodke B, Bose S, Meena AK. Stenciling-based 'prick and Print' technique for harvesting shaped corneal grafts for management of peripheral corneal perforations. Cornea. 2019.38(1):105-109. https://doi.org/10.1097/ ICO.0000000000001774
138. Gao H, Wang H, Echegaray, JJ, et al. Partial lamellar keratoplasty for peripheral corneal disease using a graft from the glycerin-preserved corneoscleral rim. Graefe's Arch Clin Exp Ophthalmol. 2014;252:963-968. https://doi.org/10.1007/ s00417-014-2642-2

139. Lin H.-C, Lee Y.-S, Chia J.-H. Management of rheumatoid arthritis-related peripheral ulcerative keratitis using glycerol-preserved corneas. Asia-Pacific J Ophthalmol. 2013;2(5):291-294. https://doi.org/10.1097/APO.0b013e318299868e 